\section{ECONOMICS}

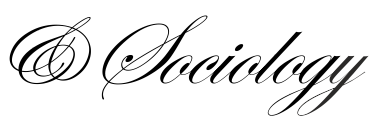

Raišienè, A.G., Wymer, W., \& Dirginčienè, V. (2021). How humor and fear in social advertising affect drivers' intention to change behaviour? The case analysis. Economics and Sociology, 14(2), 236-251. doi:10.14254/2071-789X.2021/14-2/13

\title{
HOW HUMOR AND FEAR IN SOCIAL ADVERTISING AFFECT DRIVERS' INTENTION TO CHANGE BEHAVIOUR? THE CASE ANALYSIS
}

\author{
Agota Giedrè Raišienė \\ Mykolas Romeris University, \\ Lithuania \\ E-mail:agotan@mruni.eu \\ ORCID 0000-0002-4641-7616 \\ Walter Wymer \\ University of Lethbridge, \\ Canada \\ E-mail:walter.wymer@uleth.ca \\ ORCID 0000-0002-5864-2829

\section{Valda Dirginčienė \\ Ministry of Health of The Republic \\ of Lithuania, Lithuania \\ E-mail:valda.dirginciene@sam.lt}

Received: February, 2020

1st Revision: February, 2021

Accepted: April, 2021

DOI: $10.14254 / 2071-$

789X.2021/14-2/13
JEL Classification: M37, Z13, D71
ABSTRACT. The article aims to add to knowledge of how to more effectively attain favourable marketing outcomes with respect to social marketing communications. This research sought to determine if the type of appeal had a differential influence on changing audience beliefs, audience behavioural change intentions, and audience word-of-mouth intentions. The social marketing problem in this study was unsafe driving practices, specially speeding and driving while tired or sleepy. Using a sample of 365 survey respondents in a repeated measures design, we examined the influence of appeal type on our outcome variables. We then examined the moderation effects of age and gender on the relationship between appeal type and our outcome variables. We also examined the influence of attitude toward the social marketing ad, the respondent's unsafe driving history, and the respondent's attention to the social marketing ad. With respect to the moderation effects of age and gender on the relationship between appeal type and our outcome variables, the results were not significant for audience belief change, but they were significant for audience behaviour change intentions; gender (but not age) was significant for audience WOM intentions. The research contributed to the social marketing communication research by examining the influence of appeal type on important and underresearched outcome variables. Ad execution variables were included, such as the audience's attention to the ad and their attitudes toward the ad. Finally, the effects of various audience characteristics were included in our model, specially age and gender and; most importantly for social marketers, the degree to which audience members engaged in the targeted antisocial behaviour of the research.

Keywords: social marketing communications, belief change, behaviour change, WOM, unsafe driving.

\section{Introduction}

Social marketing communications generally aims to alleviate social problems or reduce the prevalence of antisocial behaviour. Unsafe driving is serious social problem, and, 
as Lewis et al. (2019) notes, "road safety advertising can contribute to both reinforcing and transforming contemporary traffic safety culture". Here, areas of concern for social marketers has been reducing the harm caused by alcohol consumption, use of cell-phone and texting while driving, not wearing seat belt while driving, driving when tired, and other types of risky and antisocial drivers' behaviours (Cismaru \& Lavack 2015; Kubacki et al. 2015; Previte et al. 2015; Lemarié et al. 2018; Jahanfar 2018; Alvaro et al. 2018; Oviedo-Trespalacios \& Scott-Parker 2019; Buccoliero et al. 2018; Teng et al. 2019; Hayashi et al. 2019). We contribute to this stream of research, by examining aspects of social marketing communications that influence audience outcomes in the context of reducing unsafe driving behaviours. Our context are the unsafe driving behaviours of exceeding the safe speed limit (speeding) and driving while tired or sleepy.

In determining the relative effectiveness of social marketing communications, it is important to select an array of outcome, or marketing performance, variables so that the influence of the communications on the audience can be effectively evaluated (Katsikeas et al. 2016; Prisca et al. 2019; Robin et al. 2019). One contribution we make in this investigation is to assess various aspects of social marketing communications on an array of outcome variables. In the study reported in this paper, we use three outcome variables: belief change, behaviour change intentions, and word-of-mouth (WOM) intentions.

We examine the relative influence of two types of social marketing appeals: emotional versus rational appeal. Emotional versus rational appeals has received considerable attention in prior advertising research (e.g. Lim et al. 2016; Lee \& Heere 2018; Srivastava and Dorsch 2019; Kim et al., 2020). The extent literature with respect to emotional versus rational appeals indicates that the relative effectiveness of an appeal type appears to be situational (e.g. Gong \& Cummins, 2020; Strömmer et al., 2020). "It is clearly demonstrated that not one advertising appeal is superior over the other, but rather that different circumstances (i.e. product type, product category, consumer type, culture, etc.) may dictate the degree to which the use of one appeal may be more effective than the other. Thus, considerable research has been instrumental in determining those conditions under which the use of rational or emotional advertising appeals is more effective" (Shao, Grace, \& Ross 2015, p. 614). No prior research was found which examined the influence of rational versus emotional appeal type on our outcome variables, representing a gap in the literature this study fills.

In the service section, the relative appeal effectiveness varies based on service type (Zhang et al. 2014). In consumer product advertising the effectiveness of emotional versus rational appeals is influence by whether the consumer's involvement with the product is high or low (Akbari, 2015). Prior research on the differential effectiveness of appeal type finds that even audience member culture/ethnicity can exert an influence (Behboudi et al. 2014; Sadeghi et al. 2015; Srivastava \& Dorsch 2019). We contribute to this stream of research by adding to our understanding of the differential influence of emotional versus rational appeals. We examine this phenomenon in a social marketing context. As discuss previously, we examine the influence of appeal type on influence our audience's beliefs pertaining to unsafe driving practices, intentions to change their unsafe driving behaviour, and their intentions to encourage others (WOM) to drive more safely.

In our conceptual model, we take the audience's response to the social marketing message into account. For example, we examine the influence of the audience's attention to the ad and attitudes toward the ad on our outcome (marketing performance) variables. Another novel aspect of our study is that we take audience members' unsafe driving history into account. Are the more unsafe drivers influenced by the social marketing messages differently than the safer drivers? This is an important concern because social marketers would want to influence those more strongly committed to the antisocial behaviours. And 
finally, we take audience members' age in gender into account as these factors have been shown in prior research to influence outcomes (Noble, Pomering, \& Johnson 2014; Reed, Chan, \& Mikels 2014; Zotos et al. 2018; Sun et al. 2019).

\section{Conceptual background}

To realize the research contributions discussed previously, we examined the interconstruct relationships presented in the Figure 1 below.

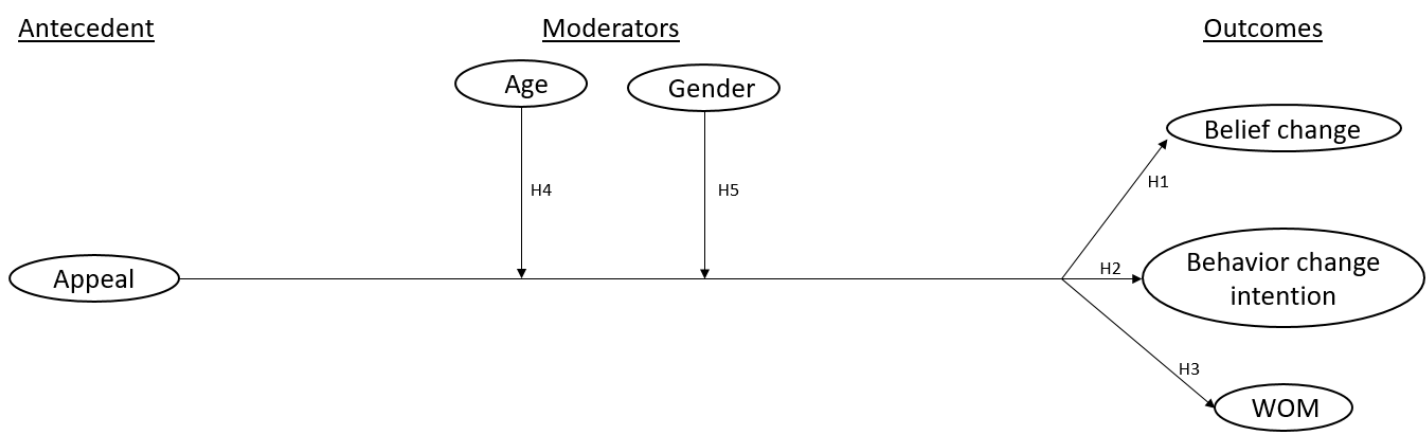

Figure 1. Appeal type's influence on audience outcomes

Source: own compilation.

We examine the influence of appeal (emotional versus rational appeal) on our three social marketing performance outcome variables: the audience's belief change, the audience's intention to change their behaviour, and the audience's intention to make positive WOM comments. We also examine whether the audience member's age or gender influences the relationship between the appeal and the outcome variables. We examine further aspects of social marketing communications as presented in the Figure 2 below.

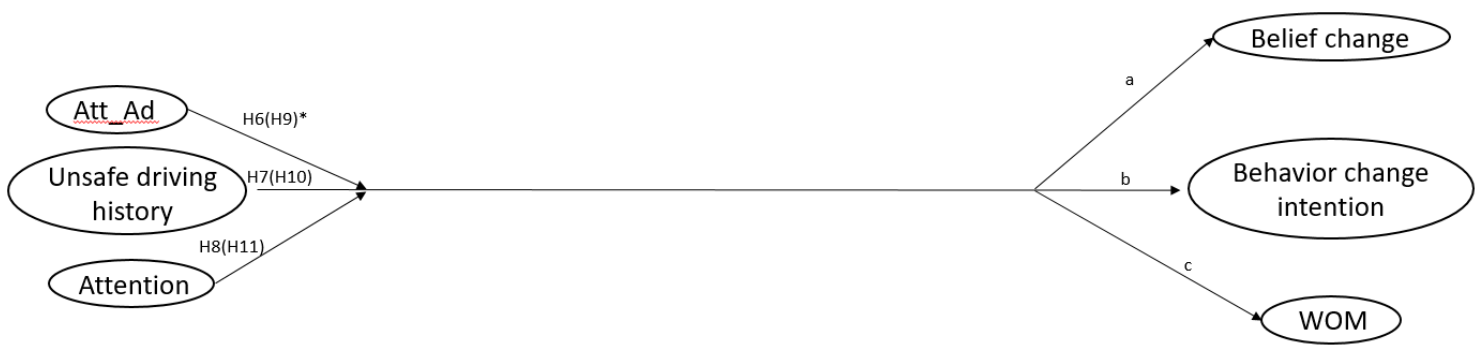

* Emotional Appeal (Rational Appeal)

Figure 2. Influence of attitude toward the ad, unsafe driving history, and attention on outcomes

Source: own compilation.

As presented in Figure 2, we examine the influences of (1) the audience's attention to the social marketing communication/ad, (2) the audience's attitude toward the social marketing communication/ad, and (3) the audience member's self-reported unsafe driving history. 


\subsection{Emotional and rational appeals}

Rational appeals stimulate a logical thinking process in the audience, to thoughtfully consider the message's content. Emotional appeals create a state of psychological arousal, whereby the individual is prepared to take certain actions (Leonidou and Leonidou 2009). Social marketing campaigns are increasingly using strong, emotional images to attract attention (Palmer 2000), but little is known about the relative effectiveness of this strategy in attaining desired audience responses.

In social marketing communications, rational appeals present reasons for why the individuals should change their beliefs or behaviours; it will be good for the individual or good for society. Emotional appeals are primarily directed at the psychological needs of the audience. Changing your beliefs or behaviours will make you feel good (or some other positive emotional change). Hence, emotional versus rational appeals represent two routes to persuasion (changing beliefs or behaviours). Which is more effective depends on a variety of factors, only some of which are fully understood. The focal outcome variables in most prior research involve favourable consumer responses to commercial advertisements. Ours are considerably different and the prior literature only offers limits guidance in predicting the influence of emotional and rational appeals in social marketing communications.

According to the elaboration-likelihood model (Petty et al., 1983, 1986), there are two routes to persuasion: the central (cognitive) and the peripheral (emotional) routes. Emotional appeals would evoke the peripheral route, whereas the rational appeals would evoke the central route. That persuasion is influenced by the degree of evoked elaboration (more thoughtful consideration of the message), while audience member involvement stimulates central processing (Petty, Cacioppo, \& Schumaun, 1983).

Our social marketing problem - unsafe driving - is a serious issue. The consequences of unsafe driving can be injury or death. Hence, social marketing ads that portray harmful consequences of unsafe driving should evoke audience involvement and, hence, stimulate greater elaboration. Thus, we have set out to test hypotheses that:

- The rational appeal will have a greater positive influence in (H1) changing audience beliefs, (H2) changing audience intentions to change their behaviour, and (H3) changing audience WOM intentions.

With respect to audience gender differences influencing the relationship between message appeal and our outcome variables, prior research offers some guidance. Prior research has found that females were more responsive to other-oriented charity appeals compared to self-oriented charity appeals than males (Brunel and Nelson 2000; Zotos et al. 2018). Furthermore, prior research has found that females tend towards more effortful elaboration processing of ad message content, whereas males then to heuristically process advertising information by focusing on cues (Darley and Smith 1995). Because social marketing ads tend to be prosocial and other-oriented and because females have a tendency towards more effortful elaboration of the ad's message content, it is reasonable to believe that the ad message effects will be greater for females than for males. Hence, we have developed the hypothesis that:

- H4: The effects of the rational appeal type on our outcome variables will be greater for females than for males.

With respect to audience age differences in influencing the relationship between message appeal and our outcome variables, prior research again offers some guidance. Age has been found to moderates the effectiveness of emotionally-framed advertising appeals. Older adults better like and recall emotional rather than rational appeals, whereas younger 
adults better like and recall rational rather than emotional appeals (Williams \& Drolet, 2005). Older adults are more likely than younger adults to attend to and remember emotionally meaningful information, especially positive information (Fung \& Carstensen, 2003). Older adults especially recall emotional appeals that focus on avoiding negative-emotional outcomes (Williams \& Drolet, 2005). Also, the experienced emotional intensity of negative emotions tends to decline with age (Barrick et al. 1989). Hence, we have set out to test the hypothesis that:

- H5: Age will have a positive influence on emotional ads compared to rational ads.

\subsection{Attitude toward the ad, unsafe driving history, and attention}

In consumer behaviour research, attitude toward the ad has been found to mediate the influence of the ad on the audience's attitude toward the brand, brand preference, and brand choice (Homer, 1990; MacKenzie \& Lutz 1989; Shimp 1981). Attitude toward the ad has also been found to influence audience viewing time of the ad (Olney, Holbrook \& Batra 1991).

The mechanisms through which attitude toward the ad influence ad effectiveness are multifaceted. The favourable attitude for the ad may stimulate favourable associations for the target brand, may create a positive mood which may create a halo effect for evaluating the message, and it may motivate greater attention to the message for greater elaboration. The following predictions are offered below:

- H6(H9): Attitude toward the ad has a positive influence on (a) belief change, $(b)$ behavioural change intentions, and (c) positive WOM intentions.

With respect to audience members' unsafe driving history, it is reasonable to believe that this variable may influence our outcome variables. We will use speeding (exceeding the legal speed limit) as an example. We will contrast occasional speeders with habitual speeders.

We believe it will be easier to change the beliefs and behaviours of the occasional speeder than the habitual speeder. The habitual speeder's behaviour has been reinforced over time for the behaviour to become habituated. The habitual speeder may experience rewards from the behaviour (getting to the destination faster, flaunting authority, identification as a risk taker). Hence, the habitual speeder has reasons for speeding, whereas the occasional speeder may just drive unsafe occasionally from carelessness.

The social marketing message aimed at reducing unsafe driving may prompt the occasional speeder to be more careful driving and to perceive speeding as less safe than originally thought. The habitual speeder has been purposely speeding for some time and has experienced insufficient negative consequences from the behaviour to warrant change. Hence, the social marketing message will have less influence on the habitual speeder:

- H7(H10): Unsafe driving history has a negative influence on (a) belief change, (b) behavioural change intentions, and (c) positive WOM intentions.

With respect to attention to the ad, it is reasonable to believe that this construct may influence our outcome variables. Obtaining attention to an advertised message is desirable. With paying some degree of attention to the message, audience members will have little recall of message content. They won't process the message content and, hence, won't be influenced by the message. As the audience's attention increases, however, the influence of the ad increases. Recall (memory of the message) increases. As attention increases, involvement increases, and message processing experiences greater elaboration (Greenwald and Leavitt, 1984). Hence, as attention to the ad increases, the influence of the ad increases. 
- H8(H11): Attention to the ad has a positive influence on (a) belief change, (b) behavioural change intentions, and (c) positive WOM intentions. hypotheses.).

Next, we report the findings of an empirical study we conducted to test our

\section{Methodological approach}

In this section, we will begin by discussing the two social marketing ads that we used to represent our two types of message appeals: emotional and rational. Then we will discuss our sample and variable measures.

\subsection{Appeal type}

A safe driving social marketing campaign would likely use a professionally produced video as the media choice. The safe driving video would likely be delivered to the target audience through appropriate channels such as television or social media on the Internet. We and our colleagues searched for available safe driving social marketing video ads. Using existing social marketing ads would allow us to use high quality videos in our study and would enhance the verisimilitude and, thus, the external validity of the study. We were able to find two safe driving social marketing video clips on YouTube that we believed appropriately represented and two appeal types.

The first social marketing video ad, Enjoy your speed to the end, ${ }^{l}$ represents the emotional appeal type. It's safe driving emphasis was on driving at a safe speed or avoiding exceeding the speed limit. It shows a humorous scene at a funeral procession. A humor is used in this advertisement. Humor evokes strong emotions in ads (Nirman, 2020). At the end of the ad, text says "Enjoy your speed. To the end."

The second social marketing video ad, Don't trust your tired self, ${ }^{2}$ represents the rational appeal type. It's safe driving emphasis was on avoiding driving while tired or sleepy. It shows a car in traffic that is swerving and eventually leaves the line to crash into on oncoming car. Text appears periodically that communicates to the viewer that the unsafe driver is not speeding or drunk, just tired. A closing text on the video says that driver fatigue is one of the top three causes of driving fatalities.

Survey respondents were instructed to watch the first social marketing ad and then answer designated questions for the first ad. After that, respondents were instructed to watch the second social marketing ad and then answer the remaining questions.

\subsection{Sample and measures}

Survey respondents were recruited using an announcement on the social media website Facebook. During the survey, we obtained 427 completed questionnaires. We had a screening question to identify nondrivers and removed nondrivers from our data, resulting in 365 completed questionnaires from adult drivers, our target population. With respect to gender, there were $110(30 \%)$ males and 255 (70\%) females in our sample.

Statistics in Lithuania as well as previous studies of driver behavior show specific features of the country. Although there is more male drivers $(59.7 \%)$ than female drivers

\footnotetext{
${ }^{1}$ https://www.youtube.com/watch?v=DhRkS-Lk jk.

2 https://www.youtube.com/watch?v=BhPhc MTyUY.
} 
(32.1\%) in the population (Žiukelis, 2017), according to the data of the state enterprise of driver examination, driving licenses and registration of vehicles, every second woman of age above 18 drives in Lithuania. Lithuania can be characterized by a large proportion of female drivers, and this is not a new phenomenon. For example, in 2011, driving licenses were issued to 19,744 women and 19,178 men. Also in 2012, more driving licenses were issued to women $(22,202)$ than to men $(21,127)$ (Regitra, 2013). What is specific, starting to age 60 , women are significantly more likely to acquire the right to drive with compared to men. For example, in 2015-2016, 113 women and 34 men became new drivers (Monkevičius, 2017).

What is more, insurance statistic shows that women cause more traffic accidents: on average, 100 women drivers cause 5.5-6 accidents per year, while 100 men drivers cause 4 (Kuktienè, 2016; Masalskienè, 2016).

As regards the scientific research of characteristics of driving behavior, female drivers have found it more difficult to control rising impulses than men (Žardeckaitè-Matulaitienè et al., 2018, p.75), whereas Machiavellianism, narcissism, verbal aggression, hostility, nonadaptive impulsiveness, and estimates of social preference scales did not differ statistically significantly between male and female groups of novice drivers (Žardeckaitè-Matulaitienė et al., 2018, p.37) Nevertheless, most recent surveys by insurance companies show that women consider themselves better drivers than men (autoreviu.lt, 09-03-2020).

In return, the gender balance is not maintained perfectly in our survey, however, we believe that this did not have a significant effect on the reliability of our study. We separately examined and compared research results by gender. Thus, whereas sample is limitation of our research, the findings could be valuable in making marketing strategy in practice.

The age distribution of our sample is presented in Table 1.

Table 1. Sample's age distribution

\begin{tabular}{ccc}
\hline $\mathrm{N}$ & $\%$ & Age range \\
\hline 34 & 9.3 & $18-25$ \\
\hline 186 & 51.0 & $26-33$ \\
\hline 75 & 20.5 & $34-41$ \\
\hline 35 & 9.6 & $42-49$ \\
\hline 22 & 6.0 & $50-57$ \\
\hline 10 & 2.7 & $58-65$ \\
\hline 3 & 0.8 & $66+$ \\
\hline
\end{tabular}

Source: own research; $\mathrm{n}=365$.

The variables and their measures are presented in Table 2. 
Table 2. Variable measures

\begin{tabular}{|c|c|}
\hline Variable & Measure \\
\hline Belief change & $\begin{array}{l}\text { Did the ad make you reconsider the (importance of driving at a } \\
\text { safer speed) (not driving while tired or sleepy)? } \\
\text { Response options: ( } 0=\text { no, } 1=\text { partly, } 2=\text { very) }\end{array}$ \\
\hline Behavioural intention & $\begin{array}{l}\text { After viewing the ad, I plan to... } \\
4=\text { never speed (drive tired or sleepy) } \\
3=\text { seldom speed (drive tired or sleepy) } \\
2=\text { speed (drive tired or sleepy) less often } \\
1=\text { not change my behavior }\end{array}$ \\
\hline WOM & $\begin{array}{l}\text { I will encourage others not to speed (not drive while tired or } \\
\text { sleepy)? } \\
\text { Response options: }(0=\text { no; } 1=y e s)\end{array}$ \\
\hline Attention to the ad & $\begin{array}{l}\text { Did the ad catch your attention? } \\
\text { Response options: }(0=\text { no; } 1=\text { yes })\end{array}$ \\
\hline Attitude toward the ad & $\begin{array}{l}\text { What is your attitude toward the ad? } \\
-1=\mathrm{I} \text { did not like the ad } \\
0=\text { Neutral } \\
1=\mathrm{I} \text { liked the ad }\end{array}$ \\
\hline Unsafe driving history & $\begin{array}{l}\text { How often do you exceed the speed limit? (How often do you } \\
\text { drive tired or sleepy?) } \\
1=\text { never } \\
2=\text { seldom } \\
3=\text { occasionally } \\
4=\text { often }\end{array}$ \\
\hline Gender & $\begin{array}{l}0=\text { male } \\
1=\text { female }\end{array}$ \\
\hline Age & $\begin{array}{l}1=18-25 \\
2=26-33 \\
3=34-41 \\
4=42-49 \\
5=50-57 \\
6=58-65 \\
7=66+ \\
(\text { Analyzed as an interval variable } 1 \rightarrow 7 \text { ) }\end{array}$ \\
\hline
\end{tabular}

Source: own research.

\section{Research results}

\subsection{Manipulation checks}

Both social marketing ads provided information. We wanted to verify that the ad representing the emotional appeal was perceived to be significantly different with respect to evoking an emotional response. As discussed previously, the emotional appeal emphasized humor in delivering its message.

After viewing each ad, respondents were asked if they found the ad funny $(0=$ no; $1=$ yes) and to verify that the ad did not evoke any emotions $(0=$ no; $1=y e s)$. The results are 
presented in Table 3. Respondents were significantly more likely to find the emotional ad funnier and significantly more likely to not have an emotional response to the rational ad.

Table 3. Manipulation check results

\begin{tabular}{|c|c|c|c|c|c|c|}
\hline \multicolumn{7}{|c|}{ I found the ad funny. $(\mathrm{N}=365, \mathrm{df}=1)$} \\
\hline Appeal type & Mean & Std. Dev & $\begin{array}{l}\text { Mean } \\
\text { Square }\end{array}$ & $\mathrm{F}$ & Sig. & Partial Eta Squared \\
\hline Emotional & 0.48 & .500 & 40.056 & $\begin{array}{c}307.32 \\
0\end{array}$ & .000 & .458 \\
\hline Rational & 0.01 & .104 & & & & \\
\hline \multicolumn{7}{|c|}{ The ad did not cause me to have any feelings. $(\mathrm{N}=365, \mathrm{df}=1)$} \\
\hline Appeal type & Mean & Std. Dev & $\begin{array}{c}\text { Mean } \\
\text { Square }\end{array}$ & $\mathrm{F}$ & Sig. & Partial Eta Squared \\
\hline Emotional & 0.06 & .243 & 14.252 & $\begin{array}{c}118.58 \\
3\end{array}$ & .000 & .246 \\
\hline Rational & 0.34 & .475 & & & & \\
\hline
\end{tabular}

Source: own research.

\subsection{Analysis}

To evaluate our first conceptual model (see Figure 1), we performed a repeated measures ANOVA on our data. The results are presented in Table 4.

The results presented in Table 4 show that the rational social marketing ad appeal was significantly more effective in influencing (H1) the audience's belief change, (H2) the audience's behaviour change intentions, and (H3) the audience's WOM intentions.

Table 4. Appeal type's influence on outcome variables

\begin{tabular}{lcccccc}
\hline IV=Appeal type. & DV=Belief change. $(\mathrm{N}=365, \mathrm{df}=1)$ & & \\
\hline Appeal type & Mean & $\begin{array}{c}\text { Std. } \\
\text { Dev }\end{array}$ & $\begin{array}{c}\text { Mean } \\
\text { Square }\end{array}$ & F & Sig. & Partial Eta Squared \\
\hline Emotional & 0.82 & .765 & 32.911 & 71.911 & .000 & .165 \\
\hline Rational & 1.25 & .651 & & & & \\
\hline
\end{tabular}

\begin{tabular}{lcccccc}
\hline IV=Appeal type. & DV=Behaviour change intentions. (N=290, df =1) & \\
\hline \multicolumn{1}{c}{ Appeal type } & Mean & $\begin{array}{l}\text { Std. } \\
\text { Dev }\end{array}$ & $\begin{array}{c}\text { Mean } \\
\text { Square }\end{array}$ & F & Sig. & Partial Eta Squared \\
& & .9046 & 23.400 & 37.786 & .000 & .116 \\
\hline Emotional & 2.078 & .9389 & & & & \\
\hline Rational & 2.479 & .8389 & & & \\
\hline
\end{tabular}

\begin{tabular}{lcccccc}
\hline IV=Appeal type. & DV=WOM. $(\mathrm{N}=365, \mathrm{df}=1)$ & & & \\
\hline Appeal type & Mean & $\begin{array}{l}\text { Std. } \\
\text { Dev }\end{array}$ & $\begin{array}{c}\text { Mean } \\
\text { Square }\end{array}$ & F & Sig. & Partial Eta Squared \\
\hline Emotional & 0.30 & .458 & 1.978 & 12.627 & .000 & .034 \\
\hline Rational & 0.40 & .491 & & & & \\
\hline
\end{tabular}

Source: own research. 
Table 5. Moderating effects of age and gender on the influence of appeal type on outcome variables

\begin{tabular}{lccccc}
\hline IV=Appeal type. $(\mathrm{N}=365, \mathrm{df}=1)$ & & & & \\
\hline \multicolumn{1}{c}{ DV } & Moderator & $\begin{array}{c}\text { Mean } \\
\text { Square }\end{array}$ & $\mathrm{F}$ & Sig. & Partial Eta Squared \\
\hline $\begin{array}{l}\text { Belief } \\
\text { change }\end{array}$ & Age & .170 & .310 & .578 & .001 \\
\hline $\begin{array}{l}\text { Belief } \\
\text { change }\end{array}$ & Gender & 1.710 & 3.117 & .078 & .009 \\
\hline $\begin{array}{l}\text { Behaviour } \\
\text { change }\end{array}$ & Age & 3.549 & 4.044 & .045 & .014 \\
\hline $\begin{array}{l}\text { Behaviour } \\
\text { change }\end{array}$ & Gender & 5.243 & 5.973 & .015 & .020 \\
\hline WOM & Age & .961 & 3.349 & .068 & .009 \\
\hline WOM & Gender & 2.432 & 8.475 & .004 & .023 \\
\hline
\end{tabular}

Source: own research.

Also, in the model presented in Figure 1, we wanted to examine the influence of age and gender on the relationship between appeal type and our outcome variables. To evaluate this portion of our conceptual model (H4-H5), we performed a repeated measures ANCOVA on our data, using age and gender as covariates. The results are presented in Tables 5 and 6 .

The results show that age is a significant moderator of the influence of appeal type on behaviour change intentions. The results from Table 5 also show that gender is a significant moderator of the influence of appeal type on behaviour change and WOM intentions. Neither age nor gender influenced the relationship between appeal type and belief change. To assist in better interpreting the findings presented in Table 5, the age and gender were regressed on the outcome variables for each appeal type. The results are presented in Table 6.

Table 6. Influence of age and gender on outcome variables

\begin{tabular}{|c|c|c|c|c|c|c|c|}
\hline Appeal type & DV & IV & B & SE & Beta & $\mathrm{T}$ & Sig. \\
\hline \multirow{2}{*}{ Emotional } & \multirow{2}{*}{$\begin{array}{l}\text { Belief } \\
\text { change }\end{array}$} & Age & .008 & .033 & .013 & .243 & .809 \\
\hline & & Gender & .192 & .087 & .115 & 2.207 & .028 \\
\hline \multirow{2}{*}{ Rational } & \multirow{2}{*}{$\begin{array}{l}\text { Belief } \\
\text { change }\end{array}$} & Age & .017 & .028 & .032 & .611 & .542 \\
\hline & & Gender & .019 & .074 & .014 & .258 & .796 \\
\hline \multirow{2}{*}{ Emotional } & \multirow{2}{*}{$\begin{array}{l}\text { Behaviour } \\
\text { change }\end{array}$} & Age & .090 & .041 & .119 & 2.161 & .031 \\
\hline & & Gender & .306 & .108 & .156 & 2.827 & .005 \\
\hline \multirow{2}{*}{ Rational } & \multirow{2}{*}{$\begin{array}{l}\text { Behaviour } \\
\text { change }\end{array}$} & Age & .036 & .038 & .053 & .941 & .347 \\
\hline & & Gender & .113 & .099 & .055 & 1.143 & .254 \\
\hline \multirow{2}{*}{ Emotional } & \multirow{2}{*}{ WOM } & Age & .34 & .020 & .090 & 1.726 & .085 \\
\hline & & Gender & .130 & .052 & .130 & 2.501 & .013 \\
\hline \multirow{2}{*}{ Rational } & \multirow{2}{*}{ WOM } & Age & .026 & .021 & .054 & 1.235 & .218 \\
\hline & & Gender & .122 & .056 & .114 & 2.192 & .029 \\
\hline
\end{tabular}

Source: own research. 
Table 7. Influence of attitude toward the ad, unsafe driving history, and attention to the ad on outcome variables

\begin{tabular}{|c|c|c|c|c|c|c|c|}
\hline $\begin{array}{l}\text { Appeal } \\
\text { type }\end{array}$ & DV & IV & B & $\begin{array}{l}\text { Std } \\
\text { error }\end{array}$ & Beta & $\mathrm{t}$ & Sig. \\
\hline \multirow{7}{*}{ Emotional } & \multirow{3}{*}{$\begin{array}{c}\text { Belief } \\
\text { change } \\
\mathrm{R}^{2}=0.198\end{array}$} & Attention & .281 & .061 & .245 & 4.583 & .000 \\
\hline & & Attitude & .278 & .056 & .264 & 4.955 & .000 \\
\hline & & \multicolumn{6}{|c|}{ Belief Change $=0.758+0.281 *$ Attention $+0.278 *$ Attitude } \\
\hline & \multirow{2}{*}{$\begin{array}{c}\text { Behavior } \\
\text { change } \\
\text { intention } \\
\mathrm{R}^{2}=0.040\end{array}$} & Attention & .225 & .085 & .165 & 2.654 & .008 \\
\hline & & \multicolumn{6}{|c|}{ Behavior Change $=2.207+0.225 *$ Attention } \\
\hline & \multirow{2}{*}{$\begin{array}{c}\text { WOM } \\
\mathrm{R}^{2}=0.037\end{array}$} & Speeding frequency & -.091 & .029 & -.161 & -3.093 & .002 \\
\hline & & \multicolumn{6}{|c|}{ WOM $=0.504+-0.091 *$ Speeding frequency } \\
\hline \multirow{9}{*}{ Rational } & \multirow{3}{*}{$\begin{array}{c}\text { Belief } \\
\text { change } \\
\mathrm{R}^{2}=0.318\end{array}$} & Attention & .331 & .048 & .360 & 6.928 & .000 \\
\hline & & Attitude & .300 & .055 & .284 & 5.481 & .000 \\
\hline & & \multicolumn{6}{|c|}{ Belief Change $=1.040+0.331 *$ Attention $+0.300 *$ Attitude } \\
\hline & \multirow{3}{*}{$\begin{array}{c}\text { Behavior } \\
\text { change } \\
\text { intention } \\
\mathrm{R}^{2}=0.085\end{array}$} & Attention & .198 & .075 & .171 & 2.640 & .009 \\
\hline & & Attitude & .223 & .087 & .165 & 2.566 & .011 \\
\hline & & \multicolumn{6}{|c|}{ Behavior Change $=2.376+0.198 *$ Attention $+0.223 *$ Attitude } \\
\hline & \multirow{3}{*}{$\begin{array}{c}\text { WOM } \\
\mathrm{R}^{2}=0.094\end{array}$} & Attention & .165 & .042 & .238 & 3.976 & .000 \\
\hline & & $\begin{array}{l}\text { Frequency of driving } \\
\text { while tired or sleepy }\end{array}$ & -.113 & .031 & -.181 & -3.582 & .000 \\
\hline & & \multicolumn{6}{|c|}{ WOM $=0.548+0.165 *$ Attention $-0.113 *$ Driving-while-tired } \\
\hline
\end{tabular}

The results presented in Table 6 show that the emotional appeal had a greater influence on females than on males for belief change, behaviour change intentions, and WOM intentions. The rational appeal had a greater influence on females than on males for only WOM intentions.

Age had much less influence on the relationship between the appeal and the outcomes variables. For the emotional appeal type, age had a significant influence on the relationship between the emotional appeal and the behaviour change intentions. Hence, for the emotional appeal, as age increased so did the influence of the appeal on behaviour change intentions. With respect to our hypothesis testing, H4 was not supported and H5 was supported.

To evaluate our second model (see Figure 2), we regressed attitude toward the ad (Att_Ad), unsafe driving history, and attention to the ad on our outcome variables. The results are presented in Table 7.

The results in Table 7 show that attitude toward the ad has a significant positive influence on belief change for the emotional appeal (Beta $=.264)$, and on belief change (Beta $=.284)$ and behaviour change intentions $($ Beta $=.165)$ for the rational appeal.

The results show that attention to the ad has a significant positive influence on belief change $($ Beta $=.245)$ and behaviour change intentions $($ Beta $=.165)$ for the emotional appeal, and on all three outcome variables for the rational appeal (Betas $=.360, .171$, and .238).

Finally, the results show that unsafe driving history (speeding history for the emotional appeal [Beta $=-.161]$ and frequency of driving while tired or sleepy for the rational appeal $[$ Beta $=-.181$ ) has a significant negative influence on WOM intentions for both the 
emotional and rational appeals. With respect to hypothesis testing, $\mathrm{H}$ 6-11 are partially supported.

Next, we will discuss the implications of this study and its findings.

\section{Discussion and findings}

Prior advertising research has found that the differential influence of emotional versus rational appeals varies by situation and much remains to be understood is this stream of research. Our study has contributed to a gap in this research stream by investigating the differential influence of emotional versus rational appeals on changing audience beliefs, changing audience behaviour change intentions, and changing audience WOM intentions. To the best of our knowledge these inter-construct relationships have not been previously examined. Social marketing communications are often aimed at changing beliefs unhealthful or antisocial and behaviours, markedly different outcomes than traditional commercial marketing which is usually aimed at stimulating brand preferences for consumer products and services. Our research contributes to the general stream of advertising research and contributes to social marketing communications research.

Our findings show that the rational appeal had significantly greater influence on our outcome variables than emotional appeal. Social marketers may find, then, that appealing to the audience's reason may increase their thoughtful consideration of the message (i.e., greater elaboration) and experience greater persuasion from the message. Our findings also indicate that females are more influenced than males by emotional appeals. Hence, while rational appeals may be more influential in general, social marketers may find emotional appeals effective with primarily female audiences.

Future research is needed to provide greater clarity to our understanding the influence of appeals on desired outcome variables. For example, the appeal type is limited to emotional or rational. Other typologies are possible and, perhaps, more informative. Also, it may be that a combination approach would be more persuasive than either a rational or emotional appeal alone. For example, a message could begin with evoking an emotional response to gain audience interest and attention, and then end with a rational appeal aimed at stimulating audience elaboration and thoughtful consideration of the message. Further research is needed to add to our knowledge on these issues.

Our findings show that the audience's attention to the message is important. This is an intuitive finding, given that a certain level of attention is prerequisite for the message to have an impact on audience memory and the evocation of thoughts and feelings. Social marketers may find that incorporating attention-gaining facets into the messages, particularly at the beginning may improve the effectiveness of their messages on attaining the desired outcomes. Future research in social marketing communications could be helpful in adding to our understanding of which types of attention-gaining tactics (e.g., humor, sex appeal, shock, fear, guilt) are most useful in various social marketing contexts.

Our findings show that attitude toward the ad can be helpful in influencing. Social marketers may find it effectiveness-enhancing to pretest audience's liking of the message prior to implementing the general social marketing campaign. Future research is needed to better understand the inter-relationship between an audience attention to the ad and its attitude toward the ad as it effects desire outcomes.

Our findings show that audience member's history, with respect to the target behaviour of interest to social marketers, affects the social marketing appeal's effectiveness in influencing the audience's WOM intentions. This is an important finding and another contribution of this research. The degree to which individuals engage in problem behaviours 
may affect their response to social marketing appeals. For example, social marketers may want to reduce the incidents of driving while under the influence of alcohol, but heavy drinkers may be differentially influenced by social marketing appeals than casual drinkers. Social marketers may want to give this issue consideration and develop strategies that are most effective for the target audience, which may be partially defined by the degree to which a group engages in a problematic behaviour. Individuals who are heavy smokers or drinkers, for example, may be more committed to the behaviour and be more resistant to persuasion or they may be more aware of their need to change and be more receptive to persuasion. More research is needed to understand more clearly the relationships between audience behaviour patterns and social marketing communication tactics.

All research is to some extent limited by its scope, context, and mythologies; and this research is no exception. Generalizations of our findings should be made with these limitations in mind. Our social marketing context was unsafe driving, particularly speeding and driving while tired or sleepy. As discussed previously, prior research has found that the influence of appeal type on outcome variables is sensitive to other factors that may interact with the relationship between the appeal and the outcome variables. Furthermore, it is quite likely that the influence of social marketing messages is affected by repeated exposures, which is typical in practice. Hence, longitudinal studies that include mere exposure effects may identify important relationships among the various constructs that a cross-sectional study would be too insensitive to find significant. Future research is needed that replicates and exceeds our study in order to improve upon its inherent limitations.

\section{References}

Akbari, M. (2015). Different impacts of advertising appeals on advertising attitude for high and low involvement products. Global Business Review, 16(3), 478-493.

Alvaro, P.K., Burnett, N., M., Kennedy, G.A., Xun Min, W.Y., McMahon, M., Barnes, M., Jackson, M., Howard, M.E. (2018). Driver education: Enhancing knowledge of sleep, fatigue and risky behaviour to improve decision making in young drivers, Accident Analysis \& Prevention, 112, 77-83, doi.org/10.1016/j.aap.2017.12.017.

Autoreviu.lt (2020) Moterys i̦sitikinusios, $\mathrm{kad}$ jos vairuoja geriau. Available on: https://www.autoreviu.lt/straipsniai/moterys-isitikinusios-kad-jos-vairuoja-geriau

Behboudi, M., Vazifehdoust, H., Najafi, K., \& Najafi, M. (2014). Using rational and emotional appeals in online advertisements for Muslim customers. Journal of Islamic Marketing, 5(1), 97-124.

Brunel, F. \& Nelson, M. (2000). Gender responses to help-self and help-others charity ad appeals: An analysis of the mediating role of world-views and values. Journal of Advertising, 24(3), 15-28.

Buccoliero, L., Bellio, E., Mazzola, M., \& Solinas, E. (2018). The role of social marketing communications in influencing "Text and Driving" Behaviors: Theory and Evidence from an international sample. GSTF Journal on Business Review (GBR), 4(3).

Cismaru, M., \& Lavack, A. M. (2015). Social marketing campaigns aimed at preventing drinking and driving: A review and recommendations. In Marketing in Transition: Scarcity, Globalism, \& Sustainability (pp. 402-402). Springer, Cham.

Darley, W., \& Smith, R. (1995). Gender differences in information processing strategies: An empirical test of the Selectivity Model in Advertising Response. Journal of Advertising, 24(1), 41-56. 
Fung, H., \& Carstensen, L. (2003). Sending memorable messages to the old: Age differences in preferneces and memory for advertisements. Journal of Personality and Social Psychology, 85(1), 163-178.

Gong, Z., Cummins, R.G. (2020). Redefining Rational and Emotional Advertising Appeals as Available Processing Resources: Toward an Information Processing Perspective, Journal of Promotion Management, 26(2), 1049-6491. doi: 10.1080/10496491.2019.1699631.

Greenwald, A. G., \& Leavitt, C. (1984). Audience involvement in advertising: Four levels. Journal of Consumer research, 11(1), 581-592.

Hayashi Y., Foreman A.M., Friedel J.E, Wirth O. (2019) Threat appeals reduce impulsive decision making associated with texting while driving: A behavioral economic approach. PLoS ONE 14(3): e0213453. https://doi.org/10.1371/journal.pone.0213453

Homer, P. M. (1990). The mediating role of attitude toward the ad: Some additional evidence. Journal of Marketing Research, 78-86.

Jahanfar, S. (2018). Driving habits - A Canadian study, Trauma, 20(3), 225-229, https://doi.org/10.1177/1460408617724816

Katsikeas, C. S., Morgan, N. A., Leonidou, L. C., \& Hult, G. T. M. (2016). Assessing performance outcomes in marketing. Journal of Marketing, 80(2), 1-20.

Kim, Cheong; Jeon, Hyeon G.; Lee, Kun C. (2020). Discovering the Role of Emotional and Rational Appeals and Hidden Heterogeneity of Consumers in Advertising Copies for Sustainable Marketing. Sustainability 12(12), 5189. https://doi.org/10.3390/su12125189

Kubacki, K., Rundle-Thiele, S., Pang, B., \& Buyucek, N. (2015). Minimizing alcohol harm: A systematic social marketing review (2000-2014). Journal of Business Research, 68(10), 2214-222.

Kuktienė, E. (2016). Amžinas klausimas: vyrai ar moterys geriau vairuoja? Available on: https://www.rinkosaikste.lt/naujienos/aktualijos/amzinas-klausimas-vyrai-ar-moterysgeriau-vairuoja

Lee, S., Heere, B. (2018). Exploring the Relative Effectiveness of Emotional, Rational, and Combination Advertising Appeals on Sport Consumer Behavior, Sport Marketing Quarterly, 27, 82-92.

Lemarié, L., Chebat, J.Ch., Bellavance, F. (2018). Reckless driving promotion and prevention: priming effects, Journal of Social Marketing, 8(2), 220-236, doi.org/10.1108/JSOCM-02-2017-0012

Leonidou, L., \& Leonidou, C. (2009). Rational versus emotional appeals in newspaper advertising: Copy, art, and layout differences. Journal of Promotion Management, 15(4), 522-546.

Lewis, I., Forward, S., Elliott, B., Kaye, S., Fleiter, J. and Watson, B. (2019) Designing and Evaluating Road Safety Advertising Campaigns, Ward, N., Watson, B. and FlemingVogl, K. (Ed.) Traffic Safety Culture, Emerald Publishing Limited, pp. 297-319. https://doi.org/10.1108/978-1-78714-617-420191018

Lim, W. M., Teh, P. L., \& Ahmed, P. K. (2016). It is not about what you read, but how you read it: the effects of sequencing rational and emotional messages on corporate and product brand attitudes. Journal of Strategic Marketing, 1-17.

MacKenzie, S. B., \& Lutz, R. J. (1989). An empirical examination of the structural antecedents of attitude toward the ad in an advertising pretesting context. The Journal of Marketing, 48-65.

Masalskienè, E. (2016). Statistika: vairuotojai subręsta perkopę 25 m. amžiaus ribą, Lietuvos draudimas. Available on: https://www.ld.lt/naujienos/statistika-vairuotojai-subrestaperkope-25-m-amziaus-riba 
Monkevičius, M. (2017). Be reikalo keikiate vyresnius vairuotojus, nors šie kartais ir sukčiauja per medicinos patikrą. Available on: 10-05-2021 https://www.alfa.lt/straipsnis/50154068/be-reikalo-keikiate-vyresnius-vairuotojus-norssie-kartais-ir-sukciauja-per-medicinos-patikra

Nirman, V. (2020). Role of emotional and humor appeals during the crisis: a study. PalArch's Journal of Archaeology of Egypt / Egyptology, 17(6), 4143 - 4149.

Noble, G., Pomering, A., \& W. Johnson, L. (2014). Gender and message appeal: Their influence in a pro-environmental social advertising context. Journal of social marketing, 4(1), 4-21.

Olney, T. J., Holbrook, M. B., \& Batra, R. (1991). Consumer responses to advertising: The effects of ad content, emotions, and attitude toward the ad on viewing time. Journal of consumer research, 17(4), 440-453.

Oviedo-Trespalacios, O., Scott-Parker, B. (2019). Fast and furious: A neglected issue in health promotion among young drivers. Health promotion journal of Australia, doi.org/10.1002/hpja.223

Palmer, H. (2000). Shock exchange. Third Sector, 17-18.

Petty, R. E., Cacioppo, J. T, \& Schumaun, D. (1983). Central and peripheral routes to advertising effectiveness: The moderating role of involvement. Journal of Consumer Research, 10(2), 135-146.

Petty, Ri. E., \& Cacioppo, J.T. (1986). The elaboration likelihood model of persuasion. In L. Berkowitz (Ed.), Advances in experimental social psychology, 123-205. New York: Academic Press.

Previte, J., Russell-Bennett, R., \& Parkinson, J. (2015). Shaping safe drinking cultures: Evoking positive emotion to promote moderate-drinking behaviour. International Journal of Consumer Studies, 39(1), 12-24.

Prisca S. Ngondo \& Anna Klyueva (2019) Fear appeals in road safety advertising: an analysis of a controversial social marketing campaign in Russia, Russian Journal of Communication, 11:2, 167-183, DOI: 10.1080/19409419.2018.1555772

Reed, A. E., Chan, L., \& Mikels, J. A. (2014). Meta-analysis of the age-related positivity effect: age differences in preferences for positive over negative information. Psychology and aging, 29(1), 1.

Regitra

Available

on: https://www.regitra.lt/lt/naujienos/lietuvoje_moteru_siekianciu_teises_vairuoti_daugiau _negu_vyru

Robin L. Nabi \& Jessica Gall Myrick (2019) Uplifting Fear Appeals: Considering the Role of Hope in Fear-Based Persuasive Messages, Health Communication, 34:4, 463-474, DOI: 10.1080/10410236.2017.1422847

Sadeghi, M., Fakharyan, M., Dadkhah, R., Khodadadian, M. R., Vosta, S. N., \& Jafari, M. (2015). Investigating the effect of rational and emotional advertising appeals of Hamrahe Aval mobile operator on attitude towards advertising and brand attitude (case study: student users of mobile in the area of Tehran). International Journal of Asian Social Science, 5(4), 233-244.

Shao, W., Grace, D., Ross, M. (2015). Self-regulatory focus and advertising effectiveness. Marketing Intelligence \& Planning, 33(4), 612-632.

Shimp, T. A. (1981). Attitude toward the ad as a mediator of consumer brand choice. Journal of advertising, 10(2), 9-48.

Srivastava, R.K. \& Dorsch, M.J. (2019). Understanding the viability of three types of approach of advertising in emerging markets, Journal of Marketing Communications, DOI: $10.1080 / 13527266.2019 .1586749$ 
Strömmer, S., Lawrence, W., Shaw, S., Correia Simao, S., Jenner, S., Barrett, M., [...] Barker, M. (2020). Behaviour change interventions: Getting in touch with individual differences, values and emotions. Journal of Developmental Origins of Health and Disease, 11(6), 589-598. doi:10.1017/S2040174420000604

Sun, J., Song, S., House, D. \& Kwon, M. (2019) Role of gender differences on individuals' responses to electronic word-of-mouth in social interactions, Applied Economics, 51(28), 3001-3014, doi: 10.1080/00036846.2018.1564015.

Teng, L., Zhao, G., Wu, Y., Fu, H., Wang J. (2019). Positive versus Negative Messaging In Discouraging Drunken Driving, Journal of Advertising Research, 59(2), 185-195. doi: 10.2501/JAR-2018-029.

Williams, P. \& Drolet, A. (2005). Age-related differences in responses to emotional advertisements. Journal of Consumer Research, 32(3), 343-354.

Žardeckaitè-Matulaitienè,, K., Endriulaitienè A., Šeibokaitè, L., Markšaitytè, R., Slavinskienè, J. (2018). Pradedančiujų vairuotojų psichologinès charakteristikos ir jų svarba kelių eismo taisyklių pažeidimams, VDU, https://doi.org/10.7220/ 9786094673375

Zhang, H., Sun, J., Liu, F., \& G. Knight, J. (2014). Be rational or be emotional: advertising appeals, service types and consumer responses. European Journal of Marketing, 48(11/12), 2105-2126.

Žiukelis, A. (2017). Eismo stereotipai: ar tikrai moterys vairuoja blogiau? Available on: https://kauno.diena.lt/naujienos/verslas/ratai/eismo-stereotipai-ar-tikrai-moterysvairuoja-blogiau-822587

Zotos, Y., Grau, S., Taylor, Ch.R. (2018). Current Research on Gender Issues in Advertising, Routledge. 